\title{
СОЦІЙЛЬНО-ПСИХОЛОГІЧНИЙ СУПРОВІД ДІТЕЙ 3 ОСОБЛИВИМИ ПОТРЕБАМИ В УМОВАХ ІНКЛЮЗИВНОГО НАВЧАННЯ
}

УДК:159. 922

\section{Абатурова Д.С.}

Студент Мелітопольського педагогічного університету ім. Богдана Хмельницького, м. Мелітополь (Украӥна)

Анотація. Останніми десятиліттями в усьому світі відбуваються докорінні зміни у розумінні та забезпеченні якісної освіти для дітей з особливими потребами. В Україні також набувають поширення новітні освітні технології, в основу яких покладено принции урахування інтересів таких дітей.

Одним з основних принципів міжнародних стандартів є право дітей $з$ особливими потребами на інтеграчію в суспільство, основою чого є забезпечення таким дітям доступу до якісної освіти. В статті розкриваються питання специифіки організації психологічного супроводу дітей з особливими потребами в умовах інклюзивного навчання.

Ключові слова: сочіально-психологічний супровід, інклюзивне навчання, діти з особливими потребами.

Постановка проблеми. Кожна дитина - особлива, але є діти, про яких говорять «особливі» не для того, щоб підкреслити унікальність здібностей, а задля того, щоб відмітити ті особливі потреби, які відрізняють їх від інших дітей. Незалежно від стану здоров’я, наявності фізичного чи інтелектуального порушення, кожна людина має право на повноцінне життя, освіту, якість якої не відрізняється від якості освіти решти людей. Саме цей принцип є основним в організації інклюзивно- го навчання дітей з особливими освітніми потребами.

Інклюзивна освіта передбачає розширення участі всіх дітей, в освітньому процесі, в тому числі дітей з особливостями психофізичного розвитку. Інклюзивне навчання несе в собі істотні зміни в організації та практичній діяльності шкіл.

Метою інклюзивної освіти є досягнення якісних змін в різних аспектах розвитку дітей цієї категорії - фізичному, соціальному, 
психологічному, розумовому, особистісному.

В Україні процес інклюзивного навчання здійснюється шляхом організації спеціальних класів, включенням дітей з вадами до звичайних класів та навчання дітей за індивідуальною формою. Окрім того, продовжують свою діяльність спеціальні школи. Тобто заклади освіти міста $є$ відкритими для навчання всіх дітей, незалежно від їхніх фізичних, інтелектуальних, соціальних чи інших особливостей.

Впровадження інклюзивного навчання в навчально-виховних процес потребує організації соціально-психологічного супроводу всіх його учасників: дітей, адміністрації, вчителів, медичних працівників, психологів, соціальних педагогів, батьків. Саме тому набуває актуальності питання організації соціальнопсихологічного супроводу дітей з особливими потребами в умовах навчального закладу.

Зв'язок проблеми із важливими науковими та практичними завданнями. Зміст та основні завдання участі психологічної служби системи освіти 3 питань впровадження інклюзивного навчання визначено низкою нормативно-правових документів, зокрема, наказом Міністерства освіти і науки України від 11.09.2009 p. № 855 «Про затвердження Плану дій щодо запровадження інклюзивного навчання у загальноосвітніх навчальних закладах на 2009-2012 роки». Заходи Плану дій розроблено $з$ метою реалізації державної політики щодо забезпечення права дітей, які потребу- ють корекції фізичного та розумового розвитку, на здобуття якісної освіти, інтеграцію їх у суспільство. 3 урахуванням основних тенденцій щодо змін у системі освіти дітей з особливими освітніми потребами окреслено напрями діяльності, які потребують підвищеної уваги, одним 3 яких є психологічний і соціальний супровід інклюзивного навчання в Україні.

3 метою залучення дітей $з$ особливими освітніми потребами у загальноосвітній простір передбачено різні форми їх навчання, зокрема, у спеціальних класах у загальноосвітніх навчальних закладах, що регламентується Положенням про спеціальні класи для навчання дітей з особливими освітніми потребами у загальноосвітніх навчальних закладах, затвердженим наказом Міністерства освіти і науки України від 09.12.2010 № 1224, зареєстрованим в Міністерстві юстиції 29.12.2010 р. за № 18707.

Зазначеними нормативними документами визначено основні завдання та напрямки психолого-педагогічного супроводу інклюзивного навчання.

Аналіз останніх досліджень і публікацій, в яких започатковано розв'язання проблеми. Протягом останнього десятиліття вітчизняні науковці, зокрема В. Бондар, А. Колупаєва, Т. Свтухова, В. Ляшенко, I. Іванова, О. Столяренко, А. Шевчук, О. Савченко та інші присвятили свої праці дослідженням проблеми залучення дітей з особливими потребами до навчання в загальноос- 
вітніх навчальних закладах, їх реабілітації та соціалізації до суспільних норм. Значний вплив на розвиток системи спеціальних навчальних закладів, удосконалення їх структури, розробку методик ранньої діагностики психічного розвитку дітей мали праці психологів Л. Виготського, О. Венгер, О. Запорожця, О. Киричука, Г. Костюка, Б. Корсунської, С. Максименка, Н. Морозової, В. Синьова, П. Таланчука, В. Тарасун, М. Ярмаченка. В них обгрунтовано принципові положення щодо особливостей розвитку психічних процесів у дітей різного віку, ролі корекційного виховання у підготовці до шкільного навчання, механізмів формування їх соціальнокомунікативної активності. В дослідженнях вчених вивчалася історія становлення і розвитку окремих напрямків спеціальної освіти дітей шкільного віку з різними психофізичними порушеннями. Одночасно аналізувалася історія виникнення наукових поглядів на ті чи інші прояви аномального розвитку та засоби їх психолого-педагогічної корекції.

Виділення невирішених раніше частин загальної проблеми. Не дивлячись на достатню розробленість проблеми інклюзивного навчання в науковій літературі, питання ефективної організації соціальнопсихологічного супроводу залишається актуальним і відкритим. Зокрема, не достатньо висвітлені питання інклюзивного навчання в умовах ДНЗ, основних напрямків методичної, кадрової та психологічної підготовки педаго- гічних працівників, які працюють в інклюзивних класах, особливостей роботи з батьками «особливих» дітей, побудови системи діагностичної, корекційної розвивальної, профілактичної роботи з дітьми, які мають вади фізичного та психічного розвитку, розробки індивідуальних навчальних планів.

Формування цілей статті. Інклюзивне навчання - це система освітніх послуг, що базується на принципі забезпечення основного права дітей на освіту та права навчатися за місцем проживання.

Мета інклюзивної школи - дати усім дітям можливість повноцінного соціального життя, активного включення в життєдіяльність колективу однолітків, тим самим забезпечуючи найбільш повну взаємодію і турботу один про одного як членів співтовариства.

Виклад основного матеріалу дослідження 3 обгрунтуванням здобутих результатів. Психолого-педагогічний супровід інклюзивного навчання та виховання потребує планування, додаткової професійної підготовки, а також контактів $з$ фахівцями, які можуть надати відповідну допомогу.

Інклюзивне навчання та виховання дітей 3 особливими потребами ставить перед освітнім закладом два серйозних запитання: «Як допомогти їм нормально розвиватись?» i «Як звести до мінімуму можливі негативні наслідки сумісного навчання з іншими дітьми?».

У розв'язанні цих завдань у системі інклюзивної освіти вирішальну роль відіграє, 
насамперед, психологічна служба кожного конкретного закладу освіти. Зокрема, практичний психолог і соціальний педагог сприяють розвиткові соціальних умінь школярів, а також надають належну моральну підтримку сім'ям дітей, їхнім рідним і вчителям, допомагають долати складні життєві ситуації. Шкільний психолог є експертом у проведенні як оцінювання розвитку, так і перспектив ситуації найближчого розвитку.

Суть діяльності шкільної психологічної служби полягає в супроводі дитини протягом iii шкільного навчання, що дає можливість впровадити шкільну психологічну діяльність у навчально-виховну педагогічну систему.

Головне завдання психолога, соціального педагога у роботі з сім'єю полягає в тому, щоб батьки з їх допомогою змогли побачити реальну перспективу розвитку своєї дитини, з'ясували можливі труднощі соціального розвитку, які виникають у певні вікові періоди, а також визначити свою роль у процесі психолого-педагогічного супроводу дитини. За необхідності психолог здійснює корекцію психічного стану батьків. Завдання психолога полягає в профілактиці невротизації або психопатизації батьків (особливо мам та бабусь) шляхом організації системи надання індивідуальних консультативних послуг.

У рамках консультативно-корекційної допомоги батькам у розв'язанні проблем психолог може використовувати різні форми роботи, до яких належить:
Система тренінгових вправ, спрямованих на формування та розвиток почуття батьківської любові «Сім кроків» [7, с. 256-262].

Психокорекційна робота 3 матерями, які виховують дітей 3 відхиленнями в розвитку «Гармонізація відносин між матір'ю та іiї дитиною» [11, с. 180-229].

Групові психокорекційні заняття «Гармонізація внутрісімейних відносин» [11, c. 229-288].

Письмові форми викладання проблеми батьківські твори: «Моя проблема», «Мій життєвий шлях», «Історія життя моєї дитини».

Психолого-педагогічна підтримка батьків є життєво необхідною, тому що саме від батьків та їх внеску в процес виховання та навчання залежить повноцінний розвиток дітей з обмеженими можливостями.

3 метою впровадження системи психолого-педагогічного супроводу дітей шкільного віку, які навчаються в умовах інклюзивної освіти, суттєвим є організація і здійснення комплексного підходу, реалізація якого передбачає поетапне впровадження інклюзивної освіти, яке потребує проведення необхідних психосоціальних та педагогічних заходів, а саме:

\section{1. Психодіагностичний етап:}

діагностика рівня розвитку дітей: виявлення індивідуальних особливостей психічного, фізичного, інтелектуального розвитку; рівня розвитку психічних процесів; діагностики соціа- 
льної зрілості, інтелекту, стилю взаємодії педагогів і батьків 3 дитиною;

тестування та анкетування педагогів та батьків на предмет готовності до здійснення інклюзивного навчання;

вивчення особливостей сім'ї, в якій виховується дитина;

психолого-педагогічне спостереження за особливостями соціальної взаємодії учнів у школах з інклюзивним навчанням.

2. Оформлення документації для здійснення психолого-педагогічного супроводу дитини з особливими потребами:

банку даних дітей відповідно до особливостей та наявних порушень;

картки здоров’я і розвитку дитини;

психологічної картки індивідуального розвитку дитини;

соціального паспорта сім'ї, в якій виховується дитина;

щоденника спостереження за дитиною в навчальному закладі;

щоденника спостереження за станом здоров'я і поведінкою дитини у позаурочний час;

3. Розробка та затвердження індивідуальних програм навчання і розвитку з рекомендаціями для педагогів і батьків, розроблених за участі різних фахівців (лікаря, психолога, соціального педагога, педагога-дефектолога, учителя-логопеда).

У межах діагностичної роботи психолого-педагогічного супроводу підлітків з осо- бливими потребами пропонуються для використання такі психодіагностичні методики:

Самооцінка, невпевненість у собі (методики М. Куна, С. А. Будассі, ДембоРубінштейна);

Тривожність, наявність страхів (Методика дослідження тривожності Спілбергера, методика «Шкала тривожності» - модифікація шкали соціально-ситуаційної тривожності О. Кондака);

Мотивація (дослідження мотивації досягнення А. Мехрабіан, проективна методика мотивації досягнення успіху та уникнення невдач Х. Гекхаузен);

Міжособистісні стосунки, взаємодія (методика діагностики міжособистісних відносин Т. Лірі, опитувальник «Роль індивіда в групі»(Кирилюк, Величко, Карпиєвич);

Самосвідомість (шкала Я-концепції Теннессі, контрольні списки П. Гоха, шкала Я -концепції Пірса-Харріса, методика дослідження «Незакінчені речення» Сакса і Леві).

Корекційний напрямок роботи психолога включає в себе систему заходів, які спрямовані на корекцію особистісних проявів поведінки та розвиток особистості клієнта за допомогою спеціальних засобів психологічної корекції (індивідуальні корекційні заняття, тренінги, ділові ігри).

Висновки і перспективи подалыших розвідок напряму. Таким чином, пріоритетними завданнями соціально-психологічного інклюзивного навчання дітей 3 особливими 
освітніми потребами є такі: недопущення появи у дитини з особливими освітніми потребами психопатологічних рис особистості під впливом особливих умов іiі розвитку; недопущення затримки не тільки в набутті знань, а й у розвитку особистості, запобігання інфантилізму; допомога дітям в опануванні системи відносин зі світом і самим собою; стабілізація емоційного стану та укріплення вольових рис; корекційно-розвивальна робота 3 наявними дефектами; стимулювання позитивного ставлення до дефекту, віри в можливість його компенсації; оптимізація спілкування дитини 3 однолітками, батьками, педагогами; розробка i впровадження відповідних форм і методів роботи як умов успішного навчання дітей з особливими потребами.

\section{Перелік використаних джерел:}

1. Битянова М. Р. Виды психолого-педагогического консилиума в образовательном учреждении / Школьный психолог. - 2002. - № 5. - С.34-37.

2. Гречко Л. М. Психологічний супровід діт ей з вадами психофізіологічного розвитку в загальноосвітній школі // Зб. наук. праць Кам'янець-Подільського державного університету: Серія соціально-педагогічна: Вип.6. Кам'янець-Подільський - 2006. - С.247-250.

3. Колупаєва A. A. Діт и 3 особливими пот ребами т а організація їх навчання: наук.-метод.посіб. [Текст] / А. А. Колупаєва, Л. О. Савчук. - К.: Наук.світ, 2010. $196 \mathrm{c}$.

4. Мамайчук И. И. Психокоррекционные т ехнологии для детей с проблемами в развитии. - СПб.: Речь, 2003. $382 \mathrm{c}$.

5. Мушинський В. П. Психолого-педагогічний супровід інклюзивного навчання в початковій школі // http:// mynvk.org.ua/inklyuzivna-osvita.

6.Нестояща К. До питання інклюзивної освіти в Українi // http://osvita.ua/school/inclusive_education/29475/

7. Оклей-Проданюк О. В. Організація робот и практ ичного психолога з сім'ями дітей в закладах інтернатного типу / Психологічна служба : науково-метод. вісн. Вип. 6 / [укл. Д. Д. Романовська , С. І. Собкова ]. - Чернівці : Технодрук, 2008. - С. 185-186.

8. Слободяник И.П. Психологическая помощь школьникам с проблемами в обучении: Практическое пособие. М.: Айрис-пресс, 2004. - 273 с.

9. Романовська Д. Д. Психологічний супровід процесу інтеграції у суспільство дітей з особливими потребами / за ред. Д. Д. Романовської, С. І. Собкової. - Чернівці: Технодрук, 2009. - С. 104-109.

\section{References (Transliteration):}

1. Bityanova $M$. R. Vidyi psihologo-pedagogicheskogo konsiliuma v obrazovatelnom uchrezhdenii / Shkolnyiy psiholog. - 2002. - \# 5. - S.34-37.

2. Grechko L. M. PsihologIchniy suprovId dItey z vadami psihofIzIologIchnogo rozvitku v zagalnoosvItnIy shkolI // Zb. nauk. prats Kam'yanets-PodIlskogo derzhavnogo unIversitetu: SerIya sotsIalno-pedagogIchna: Vip.6. Kam'yanets-PodIlskiy - 2006. - S.247-250.

3. KolupaEva A. A. DIti z osoblivimi potrebami ta organIzatsIya Yih navchannya: nauk.-metod.posIb. [Tekst] / A. A. KolupaEva, L. O. Savchuk. - K.: Nauk.svIt, 2010. - 196 s. 4. Mamaychuk I. I. Psihokorrektsionnyie tehnologii dlya detey s problemami v razvitii. - SPb.: Rech, 2003. - $382 \mathrm{~s}$.

5. Mushinskiy V. P. Psihologo-pedagogIchniy suprovId Inklyuzivnogo navchannya $\mathrm{v}$ pochatkovIy shkolI // http:// mynvk.org.ua/inklyuzivna-osvita.

6. Nestoyascha $K$. Do pitannya InklyuzivnoYi osvIti v UkraYinI // http://osvita.ua/school/ inclusive_education/29475/ 
7. Okley-Prodanyuk O. V. OrganIzatsIya roboti praktichnogo psihologa $\mathrm{z}$ sIm'yami dItey $\mathrm{v}$ zakladah Internatnogo tipu / O. V Okley-Prodanyuk, S. I. Sobkova // PsihologIchna sluzhba : naukovo-metod. vIsn. Vip. 6 / [ukl. D. D. Romanovska , S. I. Sobkova ]. - ChernIvtsI : Tehnodruk, 2008. - S. 185-186.

8. Slobodyanik I.P. Psihologicheskaya pomosch shkolnikam S problemami v obuchenii: Prakticheskoe posobie. - M.: Ayris-press, 2004. - 273 s.

9. Romanovska D. D. PsihologIchniy suprovId protsesu IntegratsIYi u suspIlstvo dItey z osoblivimi potrebami / D. D. Romanovska // za red. D. D. RomanovskoYi, S. I. SobkovoYi. - ChernIvtsI: Tehnodruk, 2009. - S. 104-109.

\section{Abaturova Darya}

Student Bohdan Khmelnytskyi Melitopolsiy Pedagogical University, Melitopol (Ukraine)

\section{SPECIFICS OF SOCIAL AND PSYCHOLO- GICAL SUPPORT FOR CHILDREN WITH SPECIAL NEEDS IN TERMS OF INCLU- SIVE EDUCATION}

\begin{abstract}
What does inclusive education? The school, which is implementing an inclusive form of education provides a child with special needs, first, the ability to get an education according to their individual abilities; secondly, to communicate and engage in common cause with their peers.

School of inclusive learning - is an educational institution open to all children regardless of their physical, social or other features. Therefore it should be no barrier learning environment tailored training programs and plans developed and worked out methods and learning. The feature of
\end{abstract}

such education should be to attract parents to work with experts to provide special services according to the different educational needs of children.

There is no doubt that inclusive educational environment formed teacher, also not a teacher, but by a team of teachers and specialists - a team that works in an interdisciplinary collaboration. In the development of an inclusive educational environment involving primary school teachers, subject teachers, speech therapists, teachers, psychologists, pedagogues-defectologists.

Keywords: social and psychological support, inclusive education, children with special needs.

\section{Абатурова Дарья}

Студент Мелитопольского педагогического университета им. Богдана Хмельницккого, г.. Мелитополь (Украина)

\section{СПЕЦИФИКА ОРГАНИЗАЦИИ СОЦИ-} АЛЬНО-ПСИХОЛОГИЧЕСКОГО СОПРОВОЖДЕНИЯ ДЕТЕЙ С ОСОБЫМИ ПОТРЕБНОСТЯМИ В УСЛОВИЯХ ИНКЛЮЗИВНОГО ОБРАЗОВАНИЯ

Аннотация. В последние десятилетиями развитии общества происходят коренные изменения в понимании и обеспечении качественного обучения для детей с особыми потребностями. В Украине также получают распространение новые образовательные технологии, в основу которых положен принцип учета интересов таких детей.

Одним из основных принципов между- 
народных стандартов является право детей с особыми потребностями на интеграцию в общество, основой которой является обеспечение таким детям доступа к качественному образованию. В статье раскрываются вопросы специфики организации психологического сопровождения детей с особыми потребностями в условиях инклюзивного обучения.

Ключевые слова: социальнопсихологическое сопровождение, инклюзивное обучение, дети с особыми потребностями. 